\title{
ROSALIND KERR
}

\author{
THE IMPRINT OF GENIUS: TASSO'S SONNET TO \\ ISABELLA ANDREINI \\ A COMMENTARY ON FERDINANDO TAVIANI'S \\ "BELLA D'ASIA:TORQUATO TASSO, GII A'T"TORI E \\ I'IMIMORTALITA”"
}

Francesco Andreini disbanded his renowned I Gelosi troupe shortly after the tragic early death of his famous wife lsabella, who suffered a miscarriage in Lyon in June 1604 on their way home from performing at the French court of Henry IV and Maria de' Medici. He then set about publishing her remaining works in an attempt to bring her some of the posthumous fame he felt she so richly deserved. Three years after her death he brought out an edition of her Lettere which opened with a dedication to Carlo Emanuele Duca di Saroia purportedly written and signed by his "umilissima e divotissima serva Isabella Andreini." Since it is dated, "Di Venetia, 14 marzo 1607,"' and since this date continues to appear in all later editions there can be no doubt that Francesco was indicating that he was speaking on the dead Isabella's behalf. Moreorer, the words that he puts into her mouth in the dedication reveal his preoccupation with giving her a voice from the grave:

Intenzione mia dunque fu di schermirmi quanto più io poteva della morte, ammaestrate così dalla Natura. Perciò non doverà parer strano ad alcuno s'io ho mandato e se tuttavia mando ne le mani degli uomini gli scritti miei, perché ognuno desidera naturalmente d'aver in se stesso e nei suoi parti, se no perpetua, almeno lunghissima vita².

If we acknowledge that the grief-stricken Francesco needed to speak as if he were one with his wife, we also have to bear in mind that lsabella's letters did not reach publication under her own direction, and hence to be wary of their authenticity: Knowing these facts about the publication of the Lettere has a bearing on our inquiry into Tasso's connection to Isabella Andreini in that a sonnet that is attributed to him appears in the collection along with other tributes and epitaphs from other well-known poets, 
including Marini. However, the following sonnet "del Sig. Torquato Tasso" dedicated "alla signora Isabella Andreini" is the only one in which she is not also directly named inside the text of the poem itself:

\author{
Quando v'ordiva il prezioso velo \\ L'alma Natura e le mortali spoglie, \\ Il bel cogliea, si come il fior si coglie, \\ Togliendo gemme in terra e lumi in Cielo: \\ E spargea fresche rose in viro gelo \\ Che l'Aura e'l Sol mai non disperde o scioglie; \\ E quanti odori l'Oriente accoglie; \\ E, perché non v'asconda invidia o zelo, \\ Ella, che fece il bel sembiante in prima, \\ Poscia il nome formò, che i rostri onori \\ Porti e rimbombi e sol bellezza esprima. \\ Felice l'alme e fortunati i cori \\ Ove con lettre d'oro Amor l'imprima \\ Nell'imagine vostra e'n cui s'adori! ${ }^{3}$
}

Since the version in the Lettere is the only one where a note has been added identifying it with Isabella Andreini and since Francesco was doing the editing, there has been considerable speculation as to whether he took it upon himself to fabricate a connection. In addition, the confusion over which are the authorized editions of 'Tasso's poems has made it very difficult to establish if, in fact, this poem was written to her at all. During the centuries-old battle Tasso scholars who are not involved with the theatre have tended to deny any possible connection to Andreini whereas theatre historians, many of whom are worshippers of Isabella, have claimed otherwise. $^{4}$

In a brilliant, well-known article, "Bella d'Asia: Torquato Tasso, gli attori e l'immortalità," 5 Ferdinando Taviani explores almost erery facet of this question and arrives at many fascinating answers. My article sets out a condensed outline of some of his findings and then offers some further arguments extending his careful reconstruction of the evidence.

What Tariani sets out to do first is to show that Angelo Solerti as Tasso's official biographer has interpreted certain past eridence incorrectly and that his pronouncement that there is no textual evidence to support the fact that Tasso wrote the sonnet to Andreini is wrong. He builds the case that Solerti, unable to find any reference to Isabella in either the manuscripts or printed editions of the Rime, decided that Francesco Bartoli in his Notizie Istoriche de' comici italiani che fiorirono intorno all'anno 1560 ai giorni presenti ${ }^{6}$ had randomly selected the sonnet because it offered such an apt 
description of Isabella." Taviani establishes that Solerti made the mistake of not going back far enough to identify the person who was responsible for first making the connection; that is, Francesco Andreini himself, as already discussed (Taviani 10-11). In order to undo the damage that Solerti's dismissal has caused, he spends considerable time showing why the counterclaims of everyone involved in trying to build the reputation of the professional actors may have actually weakened the strong evidence supporting the connection between Tasso and Andreini.

He stresses the enormous appeal for the comici in being able to claim an association with the great Tasso as part of their search for the legitimation of their profession, and proposes that having a performer-poet-literata of the stature of Isabella encouraged them to suggest parallels. By promoting her as worthy of the immortality reserved for artistic geniuses such as Tasso, they were hoping that the glory would reflect on themselves. Tariani develops his argument by pointing out an interesting fact about one of the letters in Isabella's collection. He notes that the only letter that makes a reference to an actual person is "Della morte del Signor Tasso" written on the occasion of Tasso's death (Lettere 184). Here she stresses how he has overcome death: "Morte non è altro, che un perpetuo oblio, dunque il Signor Tasso non morirà mai, poiche l'oblio non gli haurà mai forza sopra. Egli col suo sapere hà dato ad altrui tal esempio di vita, che chi vorrà lungamente vivere, bisognerà che lungamente muoia, nella nobil lettura de' suoi dottissimi scritti" (187). While this unique personal reference might simply attest to her enormous admiration for him, its inclusion acquires a more profound significance when we notice that the collection closes with another letter commemorating another real person, this time Isabella herself. An obvious addition made by Francesco Andreini, the heartwrenching "Della morte della Moglie" laments his untimely separation from his soulmate and swears to her divine spirit that he lives for nothing else but to "darti nella sua memoria vita, e renditi certa, che l'oblio perderà per me il suo nome"(267). It seems obvious that the two letters taken together suggest similarities between the two dead artists and their preoccupation with posthumous fame.

I think it is also possible to argue that the contents of the Iettere also made them an appropriate choice for suggesting a favorable comparsion between her talents and Tasso's and will return to this point later. It is important to note that most of the one hundred and fifty letters chosen for the collection are not actual letters but neoplatonic discourses on the nature of love probably taken from dialogues written for the male and female lovers for stage performances. Although this connection is easy to 
downplay since their literary merit has not stood the test of time, we need to remember that Andreini's improvisational skills were greatly admired in her life time by a wide circle of literati as well as the larger public.

In an effort to find the balance between the exaggerated claims of her theatrical fans and their too easy dismissal by Tasso's literary scholars Taviani resifts the available evidence. He locates Andreini as a member of a circle of literati, poets and publishers that included Gherardo Borgogni who became involved in the campaign to free Tasso from Ferrara. ${ }^{8}$ In 1586, as part of an intensification of the effort, Borgogni helped to bring out two publications of Tasso's works which were intended as progaganda to support his pleas for release. ${ }^{9}$ Along with a long letter of apology from Tasso, the second of these contained several poems from different poets urging his liberation were included, among them the following madrigal composed by Isabella Andreini: ${ }^{10}$

\author{
Se d'Anfion cotanto \\ Poteo l'aurata cetra, \\ Or come non impetra \\ Il tuo celeste canto \\ Tasso, pietà, ch' a noi \\ Ti renda lieto poi, \\ E s'odano i tuoi carmi \\ Cantar l'imprese gloriose e l'armi?
}

A canzonetta of Borgogni sent to Tasso after he had been freed echoes Isabella's rhyme, and beseeches him to respond by writing a poem in praise of the "Signora Isabella Andreini, comica Gelosa, intesa per Filli":

Se già del vago Aminta

Tra ninfe e tra pastori

Cantasti i vaghi amore

Canta or, Tasso, la bella

Mi dolce pastorella,

Perchè, di lei cantando,

Di mille andrai scemando

I pregi, e sarà Filli

Più degna ch'Amarilli

Più vaga ch'\maranta.

Tu dunque Filli canta

Al suon di quella cetra

Che si gran nome qui fra noi t' impetra. ${ }^{11}$ 
However, since the first known publication date of the canzonetta is 1592, much later than the 1587 date assigned to the sonnet, it is not likely that it was this request that prompted "Quando v'ordiva." Still, the 1592 canzonetta does give evidence that the campaign to associate Andrcini with Tasso had been going on since 1586. 'To corroborate his argument, Taviani refers to lines in the canzonetta that contain reminders to)Tasso of the role that Isabella's support had played in helping to get him out of prison, and then go on to suggest that if he writes for her now, Borgogni and his circle will help 'Tasso to fulfil his dream of being crowned with the laurel wreath at the Campidoglio. What can be claimed with certainty is that Isabella's madrigal marks the beginning of her actual, if tenuous, relationship with Tasso. Nuch of the argument that follows is taken up with showing that the constant efforts made to link her with him were actively instigated by such avid fans as Gherardo Borgogni, Cinzio Aldobrandini, and Comino Ventura as part of a bid to make her famous. They skewed the relationship in such a way to force a comparison between Isabella and Tasso with the deliberate goal of inferring that she was on a par with him. After her death other champions, including her husband and son, would continue to promote the association. At the end of the eighteenth century, Francesco Bartoli includes these legendary encounters between Isabella and Tasso:

Trovandosi in Roma questa virtuosa comica fu non solo dipinta, ma coronata d'alloro in simulacro colorito tra il Tasso, e il Petrarca, allorché dopo una mensa fattale dall'Eminentissimo Cardinal Cintio Aldobrandini gran mecenate de' virtuosi, dove erano per commensali sei Cardinali sapientissimi, il suddetto 'Tasso, il Cavalier de'Pazzi, Antonio ( Ongaro, ed altri poeti chiarissimi tra i quali in bella gara scrivendo e improvvisando Sonetti l'Andreini spiritosamente dopo il gran Torquato ne riportò il primo vanto. ${ }^{12}$

While Taviani is careful to point out that the equations appear grossly exaggerated (29), he is concerned to acknowledge any kernels of truth they may contain. He catches Solerti's two mistakes in the official biography where he denies that the poetry contest could have taken place, ${ }^{13}$ proving that the original source for this information came from I a Ferza, her son Giovan Battista Andreini 's demonstrably reliable account which was published in 1625 , a date close enough to her death to be verifiable by others who might have witnessed the event. ${ }^{14}$ The problem is not that the stories were false, but that they were cited as proof that Isabella was as highly regarded as Tasso. To summarize briefly; he insists that Isabella, who was esteemed as a poet in her lifetime, ${ }^{15}$ could have come second in the 
sonnet contest because that particular event was not prestigious, and the competition was slight. The far less believable claim that she was crowned in effigy with Tasso and Petrarch requires more substantial reworking which Taviani resolves by positing that it was likely part of a humble ceremony that was substituted for Tasso's longed-for coronation at the Campidoglio. At such an inconscipuous private event, Andreini's bust could have depicted her as a Muse, possibly as Calliope or Fame, rather than as herself, and hence there would have been no direct comparison between her own person and Tasso's as equally entitled to wear the laurel wreath.

Through this careful reweighing of the evidence Taviani overturns the doubts that Solerti and other scholars have cast over Andreini's association with Tasso while at the same time building the case for the compelling need of the new class of professional actors to foster such a connection in order to build respect for their art form (45). Having legitimated the basic facts behind the Tasso-Isabella legend, Taviani now returns to the question of whether "Quando v'ordiva" was written for her. Since it has been dated as belonging to the period around 1586 or 1587 it is probably that it coincides with Tasso's release from St. Anna. If this is the case then it could have been written in reply to Isabella's madrigal (Taviani 49). The most authoritative version appears under the title, "Loda la Signora Bella d'Asia," and has a handwritten note by Tasso indicating that it is "da porre nel terzo libro," a reference the Seconda Parte delle Rime, under the section "Laudi ed Encomi de' Principi e de le donne illustri" (46).

One of the problems to be faced in authenticating the sonnet is the number of different names under which it appears in various editions of the Rime. In addition to "Isabella Andreini," which only occurs in Isabella's Lettere, or in later works about theatre artists, other titles include: "Bella d'Asia," "Isabella d'Asia," Isabella...", and "Leonora N."16 Dismissing "Leonora N. because it belongs to a later time period, Taviani narrows the search down to the two titles found in manuscripts that bear Tasso's handwriting: "Bella d'Asia" found in the Estense and Ferrarese manuscripts, and "Isabella" from the 1593 Bresciano manuscript. The proof that the sonnet is for Andreini is deduced by showing the significant error made by the editor of the Parte Quinta e Sesta delle Gioie di Rime e Prose, an edition not authorized by 'Tasso that was published in Venice in 1587. The editor appears to have known that "Bella d'Asia" hid the name "Isabella" and changed the title to "Isabella d'Asia." Tasso, on the other hand, never made this adjustment. When he chose to label the poem as "Isabella," he dropped "d'Asia," because he wanted to hide her full identity. Designating 
her only by her proper and not her family name, or by the anagram "Bella d'Asia" (which can be quickly unscrambled to read "Isa]bella d' $A$ : Isabella delli Andreini" $)^{17}$ allowed him to maintain the secret of who she really was. Thus, Francesco Andreini cannot be accused of having randomly selected a sonnet of 'Tasso's that suited his wife's memory. Indeed he had no choice but to openly designate the author by name since this was the only way he could inform those who had no access to) the information that her name had been concealed by the poet himself.

Having established that the sonnet is about her, the next task is to establish what significance it had for her reputation. For Taviani, there are certain problems because he sees no references to her profession as an actress. He proposes that the sonnet was written as an attempt to endow her with the immortal fame that she so earnestly desired but could not easily achieve because of her association with the "vulgar"stage where reputations could be quickly forgotten. In fact, Tasso's praise falls very much in line with the tributes that other distinguished poets and critics showered on her even during her life time. As Tariani notes, he seems to be expanding directly on Tomasso Garzoni's extravagant praise of the then very young actress in his La Piazza universale di tutte le professioni del mondo, nobili e ignobili which was published in 1584 :

La graziosa Isabella, decoro delle scene, ornamento de' teatri, spettacolo superbo non men di virtù che di bellezza, ha illustrato anche lei questa professione in modo che, mentre il mondo durerà, mentre staranno i secoli, mentre arranno rita gli ordini ed i tempi, ogni roce, ogni lingua, ogni grido risuonerà il celebre nome d' Isabella. ${ }^{18}$

By taking the"name" of (Isa)bella and playing throughout on its connections to the abstract qualities of Beauty that bring immortality with them, 'Tasso's sonnet captures the situation that Andreini found herself in of trying to achieve greatness in a profession that could not record the genius of her performances. Some of the possible meanings that the anagram concealing her name might yield up: Clorinda, Armida or even Aminta, are all hybrids of $A$ sian and European descent, and as such capture the "lidea di una fragile armonia di principi opposti" that Tasso associated with Asia: "una delicatezza guerriera, una femminilità feroce, un turbamento della natura, della razza. La perdita d'una sicura appartenenza ad un paese, ad un sesso e ad una casa" (55). In the evolution of Isabella's claim to fame, Tasso's sonnet of praise occupies a pirotal moment because it captures both her intense wish for it, and her bravura in pursuing it so avidly:

What particularly strikes Tariani is how Tasso's sonnet actually endows Isabella with the enduring fame that her theatre fans sought so 
desperately to give her. He then unveils how this interesting paradox is actually contained in the sonnet itself by correcting a very important mistake made in the copying out of the poem. Looking over various editions of the poem, Taviani notes that Giovan Battista Licino, a friend of Borgogni and Tasso, and the editor of the Quinta and Sesta parte delle Goie di Rime e Prose had, without Tasso's knowledge, altered the final tercet which should read:

Felici l'alme e fortunati i cori

Ove con lettre d'oro Amor s'imprima

Ne l'imagine vostra, e'n cui s'adori.

Instead in the second line, Licino replaced the reflexive pronoun "si" with the objective pronoun "lo" so that the object of "imprima" and "s'adori" becomes Isabella's name, offering the easiest, even if somewhat confusing interpretation which was then adopted by a succession of theatre historians who followed Francesco Andreini's mistake:

Felici l'alme e fortunati i cori

Ove con lettre d'oro Amor l'imprima

Ne l'imagine vostra, e'n cui s'adori. (See page 86 above)

In this reading, Nature made her name, made it resonate, expressed her beauty; then, Love stamped it directly into those hearts and they adored her. The translation of the tercet included in Duchartre's The Italian Comedy approximates this meaning, but also shows the possible confusion:

Happy those souls and blessed those hearts in which Love has been stamped in letters of gold after your image, and is thus adored. (273)

This mistake, however understandable, adds another dimension to Taviani's argument that champions of the Theatre were determined to make Isabella into an unforgettable legend, even if they had to stretch the facts to do so. Paradoxically in "Quando v'ordiva," they missed out on the even greater tribute that Tasso was paying her. Making Love reflexive means that it is Love himself who has been imprinted into Isabella's image. If Love is what is imprinted rather than her name than its force is even greater, because it is not limited to her physicality, but can go beyond the now lifeless body. Rather than attaching her fame to her actual existence as an historical figure as her theatre supporters wanted, Tasso's poem exalts it to the more eternal plane of immortal genius. Taviani supports this interpretation by pointing out that in the $\mathrm{E}_{1} \mathrm{~ms}$, Tasso had changed "bra- 
mate spoglie" to "mortali spoglie" which prevents the easy conflation with "preziozo velo," making it clear that the "precious veil" and the "mortal spoils" are not the same (61). Her "mortal spoils" are easy to identify" with "il bel sembiante" and carry a clear reference to her physical attributes, but it is not so easy to consider the "precious veil" as a conventional reference to her soul since it too is being fashioned by Nature and is reprised again in the poem as "l'imagine vostro." For Taviani, it is the mystical second body, ${ }^{19}$ similar to the famous vision Tasso described in $/ /$ Messaggiero when he heard the rushing of the wind as it forced his window open:

e ne la bellissima luce m'apparve un giovine, ch' era ne' confini de la fancuillezza e de la gioventù, il quale non avea le guance d'alcun pelo ricoperte. Egli era di corpo proporzionatissimo, bianco e biondo sì che l'avorio e l'oro sarebbono stati vinti dal color de le sue carni e de' capegli: areva gli occhi azzurri, simili a quelli che da' poeti sono lodato in Ninerva; ne' quali scintillava una luce sì fattamente, che benché io fossi da lei abbagliato, prendea nondimeno diletto di rimirarlo. Era vestito d'un sottilissimo velo. (II.1. 260)

What the poem leaves us with is an exempla of the neoplatonic progression of the embodied soul's return after death to unite with the purified body to give it immortal life. Taviani's inspired article ends on the somewhat ironic note that Isabella's promoters in the theatre actually diminished the attribute of immortality in Tasso's neoplatonic sonnet when they tampered with the self-reflexive powers of Love in a shortsighted move to glorify Isabella's earthly "name." In the neoplatonic alchemic belief that Tasso is drawing on, the soul takes the form of an angelic figure that must return after death to unite with the purified body in order to give it immortal life. ${ }^{20}$ Thus "Quando v'ordiva" fits perfectly into the creation of the legends around Isabella that grew up around her both dead and alive and attests to some recognition of a transformative aspect of her living art.

For my conclusion, I include a coda that proposes that rather than simply redeeming her from her "lowly" profession, "Quando r'ordiva" may' have been a genuine tribute to her "altezza dell'ingegno" as an incomparable improviser. I would like to argue that the entire sonnet is playing with both Tasso's and Isabella's genius as possessors of "disegno," which I define here as the gift of being able to create ideas which could outdo Nature in their artifice; in this particular case through the practice of rhetoric. ${ }^{21}$ While he does not make direct mention of her acting in any specific performance, he was familiar with her stage reputation, including her 
well-known representation of the male role of Aminta. ${ }^{22}$ He had firsthand experience of her ability to improvise poetry-a skill she drew on constantly in her creation of neoplatonic dialogue for both the male and female innamorati parts she played with equal virtuosity. Many of the outstanding actors in the commedia dell'arte troupes were seeking to advance their class status by claiming that their oratorical skills as improvisors entitled them to the professional status that had been accorded to painters, sculptors and architects by virtue of their display of "disegno." The sonnet which plays with the principles of rhetorical composition by drawing attention to the arrangement and embellishment of all the aspects of Isabella's beauty pays tribute to that virtuosity.

In fact, its extended conceit of Beauty follows very closely the rules governing the impresa, a quintessential Mannerist art form that Tasso excelled in and had published a treatise on. ${ }^{23}$ In an impresa, a form derived from the conventions governing the insignia that medieval knights wore on their armour, the subject can only be fully and truly revealed through an ingenious and mysterious combination of the body or image denoting some core aspect of a person, and the motto or soul that offers some verbal expression of this attribute without overtly naming it, in order to preserve the hidden wit of the conceit. The connection of the image and the motto can only be complete when brought together in the conceit which then expressed the inner quality aspired to by the subject. Not naming Isabella Andreini or ever referring directly to anything that would identify her outright can then be explained as part of the form. ${ }^{24}$ Thus Tasso's obscuring not only of her name but of any reference to her well-known acting skills may not have been done to hide her "inferior" occupation. The ultimate purpose of the impresa was to allow the true identity of the subject to necessarily emerge. It could be argued that it was the very success of the sonnet in doing this that explains why even those who doubted that it had been written for her conceded its applicability.

$\mathrm{By}$ the end of the 15th century, Robert Klein argues that the impresa:

was by far the most important and widespread exercise of the 'symbolic faculty' [. . .] because it was by definition a manifesto of the mind rather than a symbol to be deciphered. The beauty of the work is the beauty of the ingegno-"ingenuity"; the very word concetto, used at first to describe the initial idea, came to signify a cunning form of expression. (16)

As the impresa developed into an autonomous art form, it "required an increasing number of technical qualities; instead of revealing the bearer and his (sic) temperment, it came to reveal the author and his ingegno" (18). 
"Quando v'ordiva" displays 'Tasso's ability to manipulate meaning by imposing his talents on the raw material from which he models her beauty, first creating her image, and then, without actually spelling it out, naming her accordingly: 25 As a locus communis herself, spread out over the entire universe, her body becomes a repository of the dazzling figures of speech and style created by the flowers, frost, roses, jewels, stars and perfumes that are being selected to compose her (see 2, lines $3-7$ ). ${ }^{26}$ From the outset he alerts us to the inventiveness of his oratorical eloquence by expanding her nude body into the metaphorical landscape which his rhetoric then adorns with fine clothing and ornaments. ${ }^{27}$ Thus we see Tasso as the consummate poet both adorning her body by assembling the places while at the same time leading us to her "motto" of "bella" without directly naming her because his comparison has made the image and concept one. ${ }^{28}$ In keeping with the conventions Tasso brilliantly conceals his own artifice by attributing it all to Nature (Ella, che fece il bel sembiante in prima/Poscia il nome formò), leaving it to us to tease out his greater artifice.

As the sonnet composes Isabella's body, it resembles the ways in which she would compose the commonplace books where she collected materials for improvising the stage dialogues similar to those included in the Lettere. In alluding to her beauty as being composed of rhetorical figures, it is possible to argue that Tasso is extending to her "la bellezza de l'ingegno poetico"29 - the ability of the poet to recognize what defines the beautiful. However, as we have already learned, naming her beauty is only part of the conceit since the "soul" of the poem is not completely contained in the motto, and the "prezioso velo" goes beyond merely describing the usual meaning of a disembodied soul. Tasso's interlocutor Minturno explains in I/ Minturno overo de la Bellezza that "S'a la bellezza togliete il velo, peraventura ella si trovera solamente ne l'anime separate: perché i corpi sogliono esser quasi un velo de la bellezza de l'animo" (206).

Here again is the second body that Taviani refers to as the beautiful spirit that must re-enter the dead body in order to bring it to eternal life. What leads the spirit back to the dead body is the need for reunion with the missing half of its platonic soulmate from whom it has been separated. What leads the soul to seek this union is Love, ${ }^{30}$ who might possibly be conflated with the hovering angelic figure who ultimately rejoins bodysoul-spirit into their eternal union after death. Possibly this is Tasso's alchemic Love who imprints his name in letters of gold into the hearts and souls of those other fortunate creatures who are as similarly happy and blessed as Isabella. They like her will be made perfect-as perfect as Tasso's transcendent poem can make her and them. 
Taviani's superb article has been foundational in reawakening interest in Isabella Andreini and in providing invaluable information that helps us to distinguish between her actual historical existence and her legendary fame. As she comes more sharply into focus, her accomplishments continue to impress and inspire us. It is hoped that the more scholarly work that is produced about her, the more accurately we will be able to evaluate her artistry and its significance both for early modern culture and for now. Maybe we could be those fortunate souls who are addressed at the close of the sonnet.

\section{NOTES}

${ }^{1}$ Ferdinando Taviani and Mirella Schino, Il segreto della Commedia dell'Arte (Firenze: La casa Usher, 1982) 456-7.

2Isabella Andreini, Lettere della signora Isabella Andreini padovana, comica gelosa e

academica intenta, nominata L'Accesa (Venetia: Marc'antonio Zaltieri, 1607, ad instantia di Gieronimo Bordon) 6 unnumbered.

${ }^{3}$ Lettere, 8 unnumbered.

${ }^{4}$ The spelling and punctuation is modernized, otherwise this is the same version as the 1607 , with the added title Theatre historians maintaining the connection include: Francesco Bartoli, Adolfo Bartoli, Alessandro D'Ancona, Luigi Rasi, Pierre Louis Duchartre. Tasso scholars who follow A. Solerti's dismissal of the connection as unauthorized (Vol. IV, Rime, 226), include Francesco Flora, Bruno Maier. However, see n.1190 Bruno Basile, vol. 2 (Roma: Salerno Editrice, 1994), 1206.

${ }^{5}$ Ferdinando Taviani, "Bella d'Asia: Torquato Tasso, gli attore e l'immortalità," Paragone Letteratura XXXV (1984): 2-76.

${ }^{6}$ Francesco Bartoli, Notizie Istoriche de' comici italiani che fiorirono intorno all'anno 1560 ai giorni presenti, vol. 1 (Padova: Conzatti, 1781) 36.

${ }^{7}$ Angelo Solerti, I ita di Torquato Tasso, vol.1 (Torino: Loescher, 1895) 756-7, note 4 , comments "Ciò era necessario dire perchè si vedesse che fu solo il Bartoli a referire il sonetto come diretto all'Andreini, e non gli si può perciò prestare fede intera."

${ }^{8}$ One indication that Isabella was part of their circle is the inclusion of a few of her poems in a collection of Rime di diversi celebri poeti dell'eta nostra nuovamente raccolte e poste i luce, a cura di Gio. Battista Licino (Bergamo: Comino Ventura, e Compagni, 1587). It contained poems by Torquato and Ercole Tasso, Gherardo Borgogni, Angelo Grillo, and Isabella Andreini, among others.

${ }^{9}$ Delle Rime et Prose del Sig. Torquato Tasso muovamente poste in luce. Parte Quarta. Al Sig. Gherardo Borgogni (Milano: Pietro Tini, 1686) was the first one. 
${ }^{10}$ Discorso in lode del matrimonio et un dialog d'amore del Sig. Torquato Tasso, con una lettera intorno alla revisione, alla corretione et all'accrescimento della sua Crerusalemme, di moro posto in luce, ed. Raffacle Montorfani (Milano: Pietro Tini, 1586). (Taviani, 66, note 38 describes where this is referenced.)

${ }^{11}$ G. Borgogni, Nuova Scielta di Rime (1592) 67-69.Quoted in. Solerti, I, 757. Taviani, 67, note 44, reveals very important information showing that Solerti's quoting of only the first thirteen lines of the poem added to his inability to make the connection between Isabella and 'Tasso's sonnet.

${ }^{12}$ F. Bartoli, Notizie Storiche, I, 37 (in I/ segreto, 124).

${ }^{13}$ Solerti, I, 754. The argument that Solerti advances that the contest of the improvised sonnets could not have taken place because neither Andreini, nor even more certainly Chiabrera was in Rome at the time is wrong. Andreini and I Gelosi could definitely have come to Rome because they were enroute from Naples to Florence in the fall of 1594 (Taviani 36), and the record does not list Chiabrera as present and Solerti has made a mistake in reading his name in (27).

${ }^{14}$ Gio. Battista Andreini, La Ferza. Ragionamento secondo contro l'accusa data alla commedia (Paris: Nicolao Callemont:1625), 68. (in Ferruccio Marotti and Giovanna Romei, eds., La Commedia dell'Arte e L a Società Barocca: La Professione del Teatro. vol. 2, (Milano: Bulzoni Editore, 199): 52).

${ }^{15}$ Bartoli, I, (in I/ segreto, 124, refers to "sue elegantissime Rimre non punto inferiori ad altre de' più famosi Poeti in quel secolo istesso."

${ }^{16}$ Torquato Tasso, Rime, ed. Angelo Solerti, vol. 4 (1898) 226.

${ }^{17}$ In his horoscope, her son Giovanni Battista had been designated as "Lelio delli Andreini."

${ }^{18}$ Tommaso Garzoni, La Piazza Universale di tutte le professioni del mondo, nobili e ignobili (Venezia: Ziletti, 1584) (Rpt. Il segreto 121.)

${ }^{19}$ Torquato Tasso, "Loda la signora Bella d'Asia," Le Rime, ed. Bruno Basile, vol.2, (Roma: Salerno Editrice,1994), 1206, Basile gives the note that "velo" means "corpo."

${ }^{20}$ Edinger, Edward F., The Mystery of The Coninnctio: Alcbemical Image of Individuation," transcribed and edited by Joan Dexter Blackmer. (Toronto: Inner City Books, 1994) 77-92. Rather than being something invisible, the soul that separates from the body at the moment of death takes the form of a little homunculus similar to that described by Tasso. It then flies up to join with the spirit. In the second stage the soul-spirit will reunite for a rebirth with the body and in the third, the new soul-spirit-body unity will become one with the world in what Jung calls the unus mundus. The eternal life that Isabella wanted is thus achieved through this "participation mystique" (80) in another deeper level of existencc.

${ }^{21}$ Erwin Panofsky, Idea: A Concept in Art Theory, trans. Joseph J. S. Peake (Columbia: UP of South Carolina, 1968) 85, makes his well-known argument that in the Mannerist period, "that which is to be revealed in a work of art must first be present in the mind of the artist. This mental notion Zuccari designates as dis- 
egno interno, or idea, for according to his definition the disegno interno is nothing other than 'a concept formed in our mind, that enables us explicitly and clearly to recognize any thing, whatever it may be, and to operate practically in conformance with the thing intended'." I am particularly struck with Cesare Ripa's iconic representation of Idea, Iconologia (Venezia: 1645 ed.) 362. (qtd. in Panovsky 237, n.68) especially since the notion that Idea is nurturing Nature seems particularly appropriate to this sonnet: "Una bellissima donna sollevata in aria, sarà nuda, ma ricoperta da un candido e sottilissimo velo, che tenga in cima del capo una fiamma vivace di fuoco, haurà cinta la fronte de un cerchio d'oro contesto di goie splendidissimo; terrà in braccio la figura della Natura, all quale come fanciulla dia il latte, che con l'indice della destra mano accenni un bellissimo paese, che vi stia sotto, dove siano dipinte Città, Monti, Piani, Acque, Piante, Albori, uccelli in aria e altre cose terrestri." For an English translation see George Richardson, Iconology, vol. $1,82-83$.

${ }^{22}$ Gherardo Borgogni, "Sacre ministre del divin furore," in Rime di diversi celebri poeti dell'età nostra nuovamente raccolte e poste in luce, a cura di Gio.Battista Licino (Bergamo: Comino Ventura, e Compagni, 1587) 264, includes these lines describing Isabella's theatrical accomplishments: 'L' alma Isabella anco nomar si sente,/Hor Aminta si mostra, e hora Clori;/Hor sembra Amore con la faccia ardente/Fra comici, fra Ninfe, e fra Pastori;/Hor con fronte superba, hor con dolente/In Tragico sembiante appar di fuori;/ Hor pianto versa, \& hor minaccia morte/con nobil arte, e con maniere accorte."

${ }^{23}$ Torquato Tasso, Il Conte overo de l'imprese, ed. Bruno Basile (Roma: Salerno Editrice, 1993).

${ }^{24}$ Robert Ǩlein, "The Theory of Figurative Expression in Italian Treatises on the Impresa," Form and Meaning: Essays on the Renassance and Modern Art, trans. Madeline Jay and Leon Wieseltier (New York: Viking Press, 1979) 13, explains that rules prohibiting the naming of the object represented in the drawing, and avoiding the use of a first-person verb wherever possible were intended to create the impresa as a term of a comparison and not as an autonomous expression of an idea.

${ }^{25}$ Tasso, I/ Conte, 123, refers to the imprese as "segni o imagini convenienti e simili a' nobili pensieri de l'animo, fatte per desiderio d'onore."

${ }^{26}$ Sister Joan Marie Lechner, Renaissance Concepts of the Commonplase (New York: pageant Press, 1962) 133, explains that "[f]requently the location of the places was referred to as a Garden of Eloquence or a Garden of Pleasure from which flowers and fruits might be gathered for adorning the speech. In all of these metaphors there is implied the idea of spaciousness which seems to correspond somehow with the Renaissance love of copiousness. Thus the locus communis was described as "running about the whole plain as under the vault of the sky;" as if the area which it encompassed were infinite, and the places which it employed for amplification, innumerable."

${ }^{27}$ Lechner, 135, describes how the commonplace topics became "synonymous with flowers, jewels, stars, and princely vesture for bedecking the body and, 
in fact, for decorations of all kinds which would enhance the beauty and pleasure of the speech."

28 // Conte, 122, the Forestiero Napolitano, one of the interlocutors says: "Se la comparazaione è la forma essenziale e la forma essenziale è anima de le cose animate, ne segue che la comparazione, sia l'anima: laonde l'imprese non hanno bisogno di motto, perché la comparazione sola e la pittura può farle vive."

${ }^{29}$ Tasso, I/ Minturno orero de la bellezza (Dialogue on Beauty) in Tasso's Dialogues: A Selection, with the Discourse on the Art of the Dialogue, translated with introduction and notes by Carnes Lord and Dain $A$. Trafton (Berkeley: University of California Press, 1982) 204.

${ }^{30}$ Marsiglio Ficino, "Che la Belleza è lo Splendore del Volto di Dio, Capi. IIII," in Panofsky, Appendix 1, 130, "Et noi chiamiamo Belleza quella grazia del rolto divino, et lo Amore chiamiamo la avidità dello Angelo, per la quale si invischia in tutto al volto divino. [. . . Lo splendore e la grazia di questo volto, o nello Angelo o nello animo o nella materia mondana che si sia, si debbe chiamare unversal' Belleza, e lo appetitio, che si volge inverso quella, è universale Amore."

\section{WTORKS CITED}

Andreini, Gio. Battista. La Ferza. Ragionamento secondo contro l'accusa data alla commedia. Paris: Nicolao Callemont:1625.

Andreini, Isabella. Lettere della signora Isabella Andreini padonana, comica gelosa e

acadenica intenta, nominata L'Accesa. Venetia: Marc'antonio Zaltieri, 1607, ad instantia di Gieronimo Bordon.

Bartoli, Francesco. Notizie Istoriche de' comici italiani che fiorirono intorno all'anno 1560 ai giorni presenti. vol. 1. Padova: Conzatti, 1781.

Borgogni, Gherardo. Nuora Scielta di Rime. Bergamo: Comin Ventura, 1592.

Basile, Bruno, ed. Torquato Tasso, Le Rime. Vol. II. Roma: Salerno Editrice, $1994 .$.

Duchartre, Pierre Louis. The Italian Comedy. Trans. Randolph T. Wearer. 1929. New York: Dover Publications, Inc, 1966.

Edinger, Edward. The Mystery of The Coniunctio: Alchemical Image of Individuation."

Transcribed and Edited by Joan Dexter Blackmer. Toronto: Inner City Books, 1994.

Garzoni, Tommaso. La Piazza Liniersale di tutte le professioni del mondo, nobili e ignobili. V'enezia: Ziletti, 1584.

Klein, Robert. "The Theory of Figurative Expression in Italian Treatises on the Impresa." Form and Meaning: Essays on the Renassance and Modern Art. Trans. Madeline Jay and Leon IWieseltier. New York: Viking Press, 1979.

Lechner, Sister Joan Marie Lechner. Renaissance Concepts of the Commonplaces. New York: Pageant Press, 1962.

I.icino, Giovan Battista, ed. Rime di diversi celebri poete dell'età nostra moramente raccolte e poste in luce. Bergamo:CominoVentura, e Compagni, 1587. 
Marotti, Ferruccio. and Giovanna Romei, eds., La Commedia dell'Arte e La Società Barocca: La Professione del Teatro. Vol. 2. Roma: Bulzoni Editore, 1991.

Panofsky, Erwin. Idea: A Concept in Art Theory. Trans. Joseph J.S. Peake. Columbia: U of South Carolina Press, 1968.

Richardson, George. Iconology. 1779. Vol. 1. New York \& London: Garland Publishing, 1979.

Ripa, Cesare. Iconologia. Venice, 1645.

Solerti, Angelo. I'ita di Torquato Tasso. Vol I. Torino: Ermanno Loescher, 1895. ed. Le Rime di Torquato Tasso. Edizione critica su i manoscritti e le antiche stampe a cura di Angelo Solerti. Vol IV. Rime d'occasione e d'encomio. Bologna: Romagnoli Dell'Acqua, 1902.

Tasso, Torquato. Il Conte overo del l'imprese. 1594. A cura di Bruno Basile. Roma: Salenro Editrice, 1993.

. Tasso's Dialogues: A Selection. Trans. Carnes Lord and Dain A. Trafton. Berkeley, Los Angeles: U of California P, 1982.

Taviani, Ferdinando. "Bella D'Asia, Torquato Tasso, gli attori e l'immortalità." Paragone Letteratura XXXV (1984): 3-76.

— and Mirella Schino. Il segreto della Commedia dell'Arte. Firenze: La casa Usher, 1982. 